PULLTROUSER SWAMP 
The Texas Pan American Series 


\section{Pulltrouser Swamp Ancient Maya Habitat, Agriculture, and Settlement in Northern Belize}

Edited by B. L. TURNER II and PETER D. HARRISON

4 University of Texas Press, Austin 
Copyright (C) 1983 by the University of Texas Press

All rights reserved

Printed in the United States of America

First Edition, I983

Requests for permission to reproduce material from this work should be sent to Permissions, University of Texas Press, Box 7819, Austin, Texas 78712.

The Texas Pan American Series is published with the assistance of a revolving publication fund established by the Pan American Sulphur Company.

Publication of this book was assisted by the National Science Foundation under grant BNS-8I I 5720 . Any opinions, findings, conclusions, or recommendations expressed in this publication are those of the editors and do not necessarily reflect the views of the National Science Foundation.

LIBRARY OF CONGRESS CATALOGING IN PUBLICATION DATA

Main entry under title:

Pulltrouser Swamp.

(Texas Pan American series)

Bibliography: $p$.

Includes index.

I. Mayas-Agriculture-Addresses, essays, lectures. 2. Mayas-Antiquities-Addresses, essays, lectures. 3. Pulltrouser Swamp (Belize)Antiquities-Addresses, essays, lectures. 4. Indians of Central America-Belize-Pulltrouser Swamp-Agriculture-Addresses, essays, lectures. 5. Indians of Central America-Belize-Pulltrouser SwampAntiquities-Addresses, essays, lectures. 6. Land settlement patterns, Prehistoric-Belize-Pulltrouser Swamp-Addresses, essays, lectures. 7. Belize-Antiquities-Addresses, essays, lectures. I. Turner, B. L. (Billie Lee), 1945- . II. Harrison, Peter D., I937- . III. Series. FI 435.3.A37P84 I983 972.82'6 83-5906 
Dedicated to WILLIAM M. DENEVAN pioneer in the study of pre-Hispanic wetland agriculture 
THIS PAGE INTENTIONALLY LEFT BLANK 